\title{
Synthesis and reactivity of new silyl-substituted monocyclopentadienyl molybdenum and tungsten complexes
}

\author{
F. Javier de la Mata, Pilar Giner, Pascual Royo * \\ Departamento de Quimica Inorgánica, Universidad de Alcalá, Campus Universitario, E-28871 Alcalá de Henares, Spain
}

Received 27 April 1998; received in revised form 15 July 1998

\begin{abstract}
The functionalized silylated cyclopentadienyl molybdenum and tungsten complexes $\left[\mathrm{MCp}^{\mathrm{Cl}}(\mathrm{CO})_{3} \mathrm{H}\right]\left(\mathrm{M}=\mathrm{Mo}, \mathrm{W} ; \mathrm{Cp}{ }^{\mathrm{Cl}}=\eta^{5}-\right.$ $\left.\mathrm{C}_{5} \mathrm{H}_{4} \mathrm{SiMe}_{2} \mathrm{Cl}\right)$ are prepared easily from the reaction of $\left[\mathrm{M}(\mathrm{CO})_{3}(\mathrm{NCMe})_{3}\right]$ with $\mathrm{C}_{5} \mathrm{H}_{5} \mathrm{SiMe}_{2} \mathrm{Cl}$ in refluxing THF, via $\mathrm{C}-\mathrm{H}$ activation and $\mathrm{H}$ transfer to the metal centre. Metathetical replacement of hydride by chloride is readily achieved when their methylene chloride solutions are treated with a few milliliters of $\mathrm{CCl}_{4}$ to give the chloro complexes $\left[\mathrm{MCp}{ }^{\mathrm{Cl}}(\mathrm{CO}){ }_{3} \mathrm{Cl}\right](\mathrm{M}=\mathrm{Mo}, \mathrm{W})$. The chloro-molybdenum complexes react with $1 / 2$ equivalent of deoxygenated water to give the corresponding dinuclear complexes $\left[\left\{\mathrm{Mo}(\mathrm{CO})_{3} \mathrm{X}\right\}_{2}\left(\mu-\mathrm{Cp}{ }^{\mathrm{O}} \mathrm{Cp}\right)\right],\left(\mathrm{X}=\mathrm{H}, \mathrm{Cl} ; \mathrm{Cp}^{\mathrm{O}} \mathrm{Cp}=\eta^{5}-\mathrm{C}_{5} \mathrm{H}_{4}-\mathrm{SiMe}_{2}-\mathrm{O}-\mathrm{SiMe}_{2}-\eta^{5}-\mathrm{C}_{5} \mathrm{H}_{4}\right)$, whereas their reaction with one equivalent of anhydrous $\mathrm{LiOH}$ in toluene leads to selective substitution of the silicon-bonded chlorine atom to give the hydroxo complexes $\left[\mathrm{MoCp}{ }^{\mathrm{OH}}(\mathrm{CO})_{3} \mathrm{X}\right]\left(\mathrm{X}=\mathrm{H}, \mathrm{Cl} ; \mathrm{Cp}^{\mathrm{OH}}=\eta^{5}-\mathrm{C}_{5} \mathrm{H}_{4} \mathrm{SiMe}_{2} \mathrm{OH}\right)$. These hydroxosilyl complexes can be transformed into the dinuclear compounds $\left[\left\{\mathrm{Mo}(\mathrm{CO})_{3} \mathrm{X}\right\}_{2}\left(\mu-\mathrm{Cp}{ }^{\circ} \mathrm{Cp}\right)\right]$ by heating $\left(50^{\circ} \mathrm{C}, 2 \mathrm{~h}\right)$ or by their reaction with one equivalent of the respective hydrido and chloro derivatives $\left[\mathrm{MoCp}^{\mathrm{Cl}}(\mathrm{CO})_{3} \mathrm{X}\right]$. Total decarbonylation of the hydrido compounds results from oxidation with a stoichiometric amount of $\mathrm{PCl}_{5}$ to give the paramagnetic molybdenum(V) and tungsten(V) complexes $\left[\mathrm{MCp}^{\mathrm{Cl}} \mathrm{Cl}{ }_{4}\right](\mathrm{M}=\mathrm{Mo}, \mathrm{W})$. Reactions of these complexes with one equivalent of $\mathrm{NH}_{2} \mathrm{R}$ in the presence of $\mathrm{NEt}_{3}$ yield the imido derivatives [MCp ${ }^{\mathrm{Cl}}(\mathrm{NR}) \mathrm{Cl}_{2}$ ] $\left(\mathrm{M}=\mathrm{Mo}, \mathrm{R}=2,6-\mathrm{Me}_{2}-\mathrm{Ph} ; \mathrm{M}=\mathrm{W}, \mathrm{R}={ }^{t} \mathrm{Bu}\right)$ and subsequent oxidation of the tungsten complex with $1 / 2$ equivalent of $\mathrm{PCl}{ }_{5}$ gives $\left[\mathrm{WCp}^{\mathrm{Cl}}\left(\mathrm{N}^{t} \mathrm{Bu}\right) \mathrm{Cl}_{3}\right]$. Reduction of $\left[\mathrm{MoCp}^{\mathrm{Cl}} \mathrm{Cl}_{4}\right]$ with two equivalents of $\mathrm{Na} / \mathrm{Hg}$ gives the dinuclear molybdenum(III) complex $\left[\mathrm{MoCp}{ }^{\mathrm{Cl}}\right]_{2}(\mu-\mathrm{Cl})_{4}$. All of the reported compounds were characterized by elemental analysis and ${ }^{1} \mathrm{H}$ - and ${ }^{13} \mathrm{C} \mathrm{NMR}-\mathrm{spectroscopy}$. (C) 1999 Elsevier Science S.A. All rights reserved.
\end{abstract}

Keywords: Molybdenum; Tungsten; Cyclopentadienyl; Chlorosilyl

\section{Introduction}

Since the discovery and early investigations of chromocene [1] the study of cyclopentadienyl Group 6 metal derivatives has played a prominent role. Compounds containing halide ligands in addition to the $\mathrm{Cp}$ ring are particularly useful as synthons for other organometallic systems [2]. We reported [3] the synthesis of some dinuclear hydrido- and chloro-tricarbonyl cyclopentadienyl molybdenum and tungsten complexes of the type investigated extensively by Legzdins [3]. Lately, $\eta^{5}$ -

\footnotetext{
* Corresponding author. Tel.: +34-1-8854765; fax: + 34-18854683; e-mail: proyo@inorg.alcala.es.
}

cyclopentadienyl imido Group 6 metal complexes have been reported also [4] and more recently we published alternative methods to isolate molybdenum and tungsten imido derivatives in high yields [5].

In addition, there has been growing interest in the development of supported catalytic systems because the attachment of metal complexes to organic polymers or inorganic supports [6] combines the most advantageous properties of both homogeneous and heterogeneous catalysis. Functionalized silylated cyclopentadienyl derivatives are good candidates for this purpose. In this paper, we report an efficient approach for the synthesis of new silyl-substituted monocyclopentadienyl molybdenum and tungsten complexes and describe some as- 
pects of the comparative reactivity of their siliconchloro and metal-chloro bonds.

\section{Results and discussion}

\subsection{Preparative methods}

The three acetonitrile ligands in $\left[\mathrm{M}(\mathrm{CO})_{3}(\mathrm{NCMe})_{3}\right]$ are substituted easily, with simultaneous ring $\mathrm{C}-\mathrm{H}$ activation and hydrogen transfer [7], by reaction with $\mathrm{C}_{5} \mathrm{H}_{5} \mathrm{SiMe}_{2} \mathrm{Cl}$ in refluxing $\mathrm{THF}$ to give $\left[\mathrm{MCp}^{\mathrm{Cl}}(\mathrm{CO})_{3} \mathrm{H}\right]$ ( $\mathrm{M}=\mathrm{Mo}$ (1) [8], W (2); $\left.\mathrm{Cp}^{\mathrm{Cl}}=\eta^{5}-\mathrm{C}_{5} \mathrm{H}_{4} \mathrm{SiMe}_{2} \mathrm{Cl}\right)$.

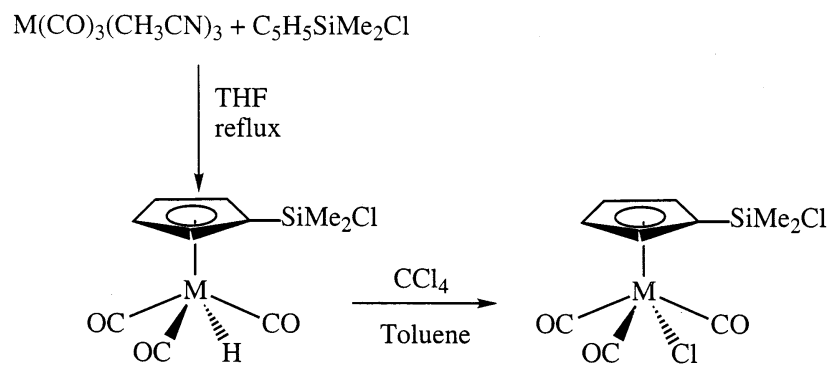

Scheme 1.

Metathetical replacement of hydride by chloride is readily achieved when methylene chloride solutions of 1 and 2 are stirred with a few milliliters of $\mathrm{CCl}_{4}$, giving the chloro-complexes $\left[\mathrm{MCp}^{\mathrm{Cl}}(\mathrm{CO})_{3} \mathrm{Cl}\right](\mathrm{M}=\mathrm{Mo}$ (3), W (4)) (Scheme 1). These complexes are obtained as orange crystalline solids, although they become oily materials after several hours at room temperature. Complexes 1-4 are soluble in aromatic and saturated hydrocarbons, methylene chloride and THF are air and moisture sensitive and have to be stored in rigorously dry, anaerobic conditions. They are thermally stable and no decomposition was observed below $100^{\circ} \mathrm{C}$. Particularly interesting was the thermal decomposition of complex 3 monitored by ${ }^{1} \mathrm{H}-\mathrm{NMR}$ spectroscopy, which gave a mixture of $\left[\mathrm{MoCp}^{\mathrm{Cl}}\left(\mu-\mathrm{Cl}_{2}\right)\right]_{2}$ (11) and another unidentified product (presumably $\left[\mathrm{MoCp}^{\mathrm{Cl}}(\mathrm{CO})_{3}\right]_{2}$ or its decomposition product) when heated for $12 \mathrm{~h}$ at $120^{\circ} \mathrm{C}$. Identification of complex 11 was made by comparison of its NMR data with that of a pure sample of $\mathbf{1 1}$ prepared by an alternative method (see below).

Complex 3 contains both $\mathrm{Si}-\mathrm{Cl}$ and $\mathrm{Mo}-\mathrm{Cl}$ bonds each available for substitution reactions. Selective hydrolysis of the $\mathrm{Si}-\mathrm{Cl}$ bond would be desirable in order to attach these complexes to acidic inorganic oxides as supports [9]. Hydrolysis reactions were carried out to investigate the relative reactivity of the $\mathrm{Si}-\mathrm{Cl}$ and $\mathrm{Mo}-$ $\mathrm{Cl}$ bonds in $\mathbf{3}$ and extended to the hydrido complex $\mathbf{1}$ (Scheme 2). Both complexes 1 and 3 reacted with $1 / 2$ equivalent of deoxygenated water in toluene with evolution of $\mathrm{HCl}$, giving the corresponding dinuclear complexes $\left[\left\{\mathrm{Mo}(\mathrm{CO})_{3} \mathrm{X}\right\}_{2}\left(\mu-\mathrm{Cp}^{\mathrm{O}} \mathrm{Cp}\right)\right],(\mathrm{X}=\mathrm{H}$ (5), $\mathrm{Cl}$ (6); $\left.\mathrm{Cp}{ }^{\mathrm{O}} \mathrm{Cp}=\eta^{5}-\mathrm{C}_{5} \mathrm{H}_{4}-\mathrm{SiMe}_{2}-\mathrm{O}-\mathrm{SiMe}_{2}-\eta^{5}-\mathrm{C}_{5} \mathrm{H}_{4}\right)$. Selective hydrolysis of the $\mathrm{Si}-\mathrm{Cl}$ bond was observed in both cases even when an excess of water was used. Complexes 5 and $\mathbf{6}$ were isolated as orange-red solids,

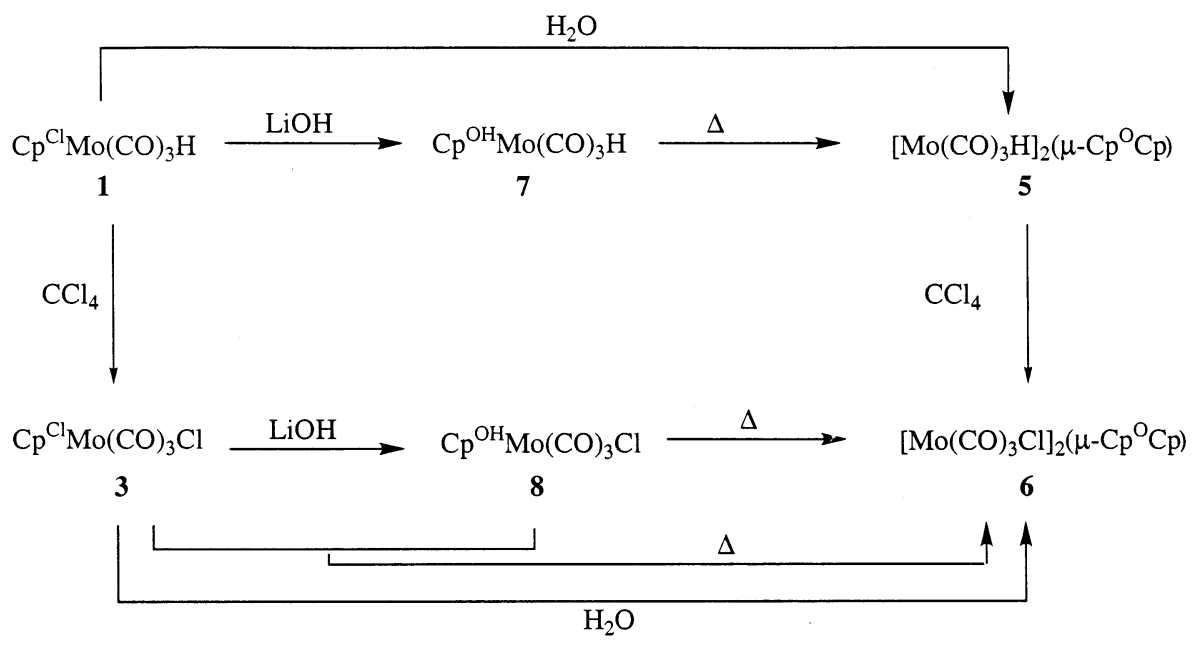

$$
\begin{aligned}
& \mathrm{Cp}^{\mathrm{Cl}}=\mathrm{C}_{5} \mathrm{H}_{4} \mathrm{SiMe}_{2} \mathrm{Cl} \\
& \mathrm{Cp}^{\mathrm{OH}}=\mathrm{C}_{5} \mathrm{H}_{4} \mathrm{SiMe}_{2} \mathrm{OH} \\
& \mathrm{Cp}^{\mathrm{O}} \mathrm{Cp}=\left(\mathrm{C}_{5} \mathrm{H}_{4} \mathrm{SiMe}_{2}\right)_{2}(\mu-\mathrm{O})
\end{aligned}
$$


soluble in aromatic hydrocarbons and chlorinated solvents. Complex 6 was air and moisture stable and both were thermally stable below $150^{\circ} \mathrm{C}$. A similar selective reaction at the $\mathrm{Si}-\mathrm{Cl}$ bond was observed when complex 3 was treated with one equivalent of the stronger nucleophile, anhydrous $\mathrm{LiOH}$ in toluene at room temperature to give the hydroxosilyl complex $\left[\mathrm{MoCp}{ }^{\mathrm{OH}}(\mathrm{CO})_{3} \mathrm{Cl}\right] \quad(8) \quad\left(\mathrm{Cp}^{\mathrm{OH}}=\eta^{5}-\mathrm{C}_{5} \mathrm{H}_{4} \mathrm{SiMe}_{2} \mathrm{OH}\right)$, which was isolated as a red microcrystalline solid in quantitative yield. An analogous reaction of a benzene- $\mathrm{d}_{6}$ solution of $\mathbf{1}$ with one equivalent of anhydrous $\mathrm{LiOH}$ in a sealed NMR tube yielded the related hydrido complex $\left[\mathrm{MoCp}{ }^{\mathrm{OH}}(\mathrm{CO})_{3} \mathrm{H}\right](7)$, although it was always contaminated with small amounts of the dinuclear compound 5, which prevented isolation of $\mathbf{7}$ as a pure compound. Complexes 7 and 8 can be transformed into the dinuclear compounds 5 and $\mathbf{6}$ on heating $\left(50^{\circ} \mathrm{C}, 2 \mathrm{~h}\right)$ or by reaction with one equivalent of 1 and $\mathbf{3}$, respectively.

We observed no reactivity at the $\mathrm{Mo}-\mathrm{Cl}$ bond in the reactions described above. This contrasts with the behaviour reported for the titanium and niobium derivatives [10], where both the $\mathrm{Si}-\mathrm{Cl}$ and the $\mathrm{Ti}-\mathrm{Cl}$ bonds were simultaneously involved in reactions with protic reagents such as water, and reactions with stronger nucleophilic reagents took place selectively at the $\mathrm{M}-\mathrm{Cl}$ bonds. This contrasting behaviour was anticipated since the Lewis acidity of the Mo(II) centre is lower than the $\mathrm{Ti}(\mathrm{IV})$ and $\mathrm{Nb}(\mathrm{V})$ centres.

Total decarbonylation of the hydrido complexes $\mathbf{1}$ and $\mathbf{2}$ was achieved by their oxidation with a stoichiometric amount of $\mathrm{PCl}_{5}$ to give the paramagnetic molybdenum(V) and tungsten(V) complexes $\left[\mathrm{MCp}^{\mathrm{Cl}} \mathrm{Cl}_{4}\right] \quad(\mathrm{M}=\mathrm{Mo}$ (9), W (10)). However, the molybdenum complex 9 was obtained better by oxidation of the chloro derivative 3 with $\mathrm{PCl}_{5}$. Complexes 9 and $\mathbf{1 0}$ were found to be very moisture sensitive, reacting immediately with traces of water, and must be stored under rigorously dry conditions. They are soluble in aromatic hydrocarbons and chlorinated solvents but insoluble in saturated hydrocarbons such as $n$-hexane.
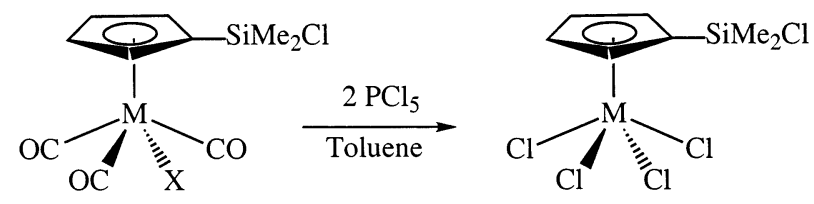

$M=M o, X=C l(3)$
$M=W, \quad X=H$

$$
\begin{aligned}
& M=M o(9) \\
& M=W \quad(10)
\end{aligned}
$$

Reduction of 9 with two equivalents of sodium amalgam $(10 \%$ of $\mathrm{Na})$ in toluene, followed by extraction into methylene chloride gave the molybdenum(III) complex $\left[\mathrm{MoCp}^{\mathrm{Cl}}\left(\mu-\mathrm{Cl}_{2}\right)\right]_{2}$ (11) in $70 \%$ yield, which could be reoxydized to 9 by addition of a stoichiometric amount of $\mathrm{PCl}_{5}$. Complex $\mathbf{1 1}$ is an air and moisture sensitive compound, sparingly soluble in aromatic hydrocarbons and soluble in chlorinated solvents.

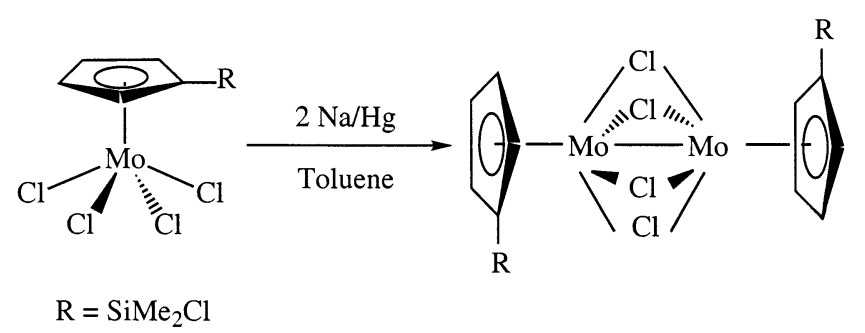

Isolation of new cyclopentadienyl molybdenum and tungsten imido derivatives was attempted by reaction of complexes $\mathbf{9}$ and $\mathbf{1 0}$ with amines. Reaction of $\mathbf{1 0}$ with one equivalent of $\mathrm{NH}_{2}{ }^{t} \mathrm{Bu}$ in the presence of two equivalents of triethylamine gave, after removing the ammonium salt formed, [WCp $\left.{ }^{\mathrm{Cl}}\left(\mathrm{N}^{t} \mathrm{Bu}\right) \mathrm{Cl}_{2}\right]$ (12), which could be oxidised to the diamagnetic tungsten(VI) derivative $\left[\mathrm{WCp}^{\mathrm{Cl}}\left(\mathrm{N}^{t} \mathrm{Bu}\right) \mathrm{Cl}_{3}\right.$ ] (13) by addition of $1 / 2$ equivalent of $\mathrm{PCl}_{5}$. Complex 9 also reacted with $\mathrm{NH}_{2}^{t} \mathrm{Bu}$ in the presence of $\mathrm{NEt}_{3}$, but in this case the reaction product could not be characterized and its reaction with $\mathrm{PCl}_{5}$ did not allow the identification of any molybdenum(VI) species. Nevertheless, a similar reaction of 9 with $\mathrm{NH}_{2}\left(2,6-\mathrm{Me}_{2}-\mathrm{C}_{6} \mathrm{H}_{3}\right)$ afforded the paramagnetic complex $\left[\mathrm{MoCp}{ }^{\mathrm{Cl}}\left(\mathrm{N}-2,6-\mathrm{Me}_{2}-\mathrm{C}_{6} \mathrm{H}_{3}\right) \mathrm{Cl}_{2}\right]$ (14), which was characterized by elemental analysis and IR spectroscopy. Subsequent oxidation of $\mathbf{1 4}$ with $1 / 2$ equivalent of $\mathrm{PCl}_{5}$ failed and we could not characterize any organometallic product in the resulting mixture (Scheme 3).

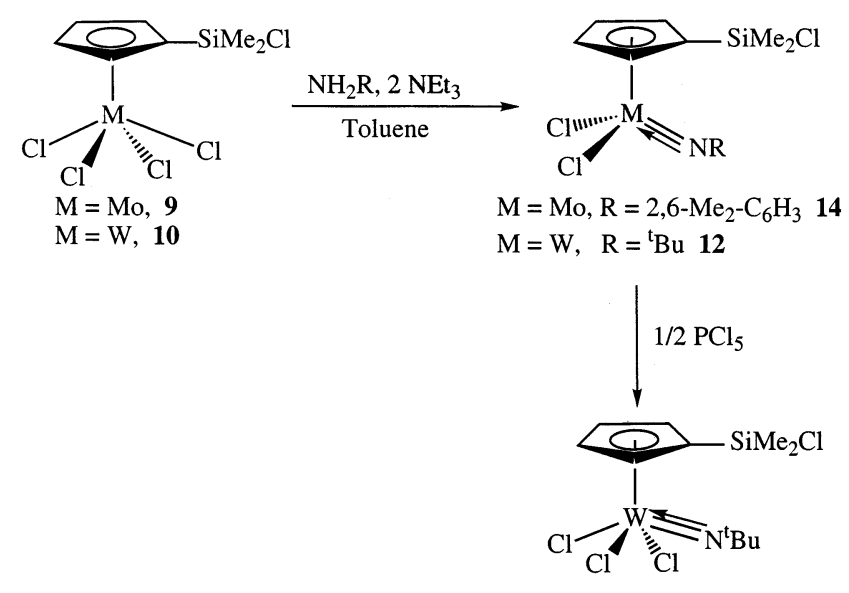

13

Scheme 3. 
Table 1

${ }^{1} \mathrm{H}-\mathrm{NMR}\left(\mathrm{C}_{6} \mathrm{D}_{6}\right)^{\mathrm{a}}$ data for complexes $\mathrm{MCp}(\mathrm{CO})_{3} \mathrm{X}(\mathrm{X}=\mathrm{H}, \mathrm{Cl})$

\begin{tabular}{|c|c|c|}
\hline Complex & $-\mathrm{C}_{5} \mathrm{H}_{4}-$ & $-\mathrm{SiMe}_{2}-$ \\
\hline $\mathrm{MoCp}^{\mathrm{Cl}}(\mathrm{CO})_{3} \mathrm{H}(\mathbf{1})$ & $4.75,4.69\left(\mathrm{AA}^{\prime} \mathrm{BB}^{\prime}\right.$ spin system, $\left.4 \mathrm{H}\right)$ & $0.32(\mathrm{~s}, 6 \mathrm{H})$ \\
\hline $\mathrm{WCp}^{\mathrm{Cl}}(\mathrm{CO})_{3} \mathrm{H}(\mathbf{2})$ & $4.66(\mathrm{~m}, 4 \mathrm{H})$ & $0.32(\mathrm{~s}, 6 \mathrm{H})$ \\
\hline $\mathrm{MoCp}^{\mathrm{Cl}}(\mathrm{CO})_{3} \mathrm{Cl}(\mathbf{3})$ & $4.69,4.52\left(\mathrm{AA}^{\prime} \mathrm{BB}^{\prime}\right.$ spin system, $\left.4 \mathrm{H}\right)$ & $0.41(\mathrm{~s}, 6 \mathrm{H})$ \\
\hline $\mathrm{WCp}^{\mathrm{Cl}}(\mathrm{CO})_{3} \mathrm{Cl}(\mathbf{4})$ & $4.66(\mathrm{~m}, 4 \mathrm{H})$ & $0.41(\mathrm{~s}, 6 \mathrm{H})$ \\
\hline$\left[\mathrm{Mo}(\mathrm{CO})_{3} \mathrm{H}\right]_{2}\left(\mu-\mathrm{Cp}^{\mathrm{O}}\right)(\mathbf{5})$ & $4.83,4.79\left(\mathrm{AA}^{\prime} \mathrm{BB}^{\prime}\right.$ spin system, $\left.4 \mathrm{H}\right)$ & $0.17(\mathrm{~s}, 6 \mathrm{H})$ \\
\hline$\left[\mathrm{Mo}(\mathrm{CO})_{3} \mathrm{Cl}\right]_{2}\left(\mu-\mathrm{Cp}^{\mathrm{O}}\right)(\mathbf{6})$ & $4.84,4.76\left(\mathrm{AA}^{\prime} \mathrm{BB}^{\prime}\right.$ spin system, $\left.4 \mathrm{H}\right)$ & $0.23(\mathrm{~s}, 6 \mathrm{H})$ \\
\hline $\left.\mathrm{MoCp} \mathrm{OH}_{(\mathrm{CO}}\right)_{3} \mathrm{H}(7)$ & $4.83,4.76\left(\mathrm{AA}^{\prime} \mathrm{BB}^{\prime}\right.$ spin system, $\left.4 \mathrm{H}\right)$ & $0.11(\mathrm{~s}, 6 \mathrm{H})$ \\
\hline $\left.\mathrm{MoCp} \mathrm{OH}_{(\mathrm{CO}}\right)_{3} \mathrm{Cl}(\mathbf{8})$ & $4.81,4.44\left(\mathrm{AA}^{\prime} \mathrm{BB}^{\prime}\right.$ spin system, $\left.4 \mathrm{H}\right)$ & $0.22(\mathrm{~s}, 6 \mathrm{H})$ \\
\hline
\end{tabular}

${ }^{\text {a }}$ Chemical shifts are given in ppm. Coupling constants are given in $\mathrm{Hz}$.

\subsection{Structural study}

Spectroscopic data for all the new complexes reported are given in Section 4. The IR spectra of all complexes show a characteristic band at $1250 \mathrm{~cm}^{-1}$ due to the $\mathrm{SiMe}_{2}$ group and the new carbonyl complexes show $v(\mathrm{CO})$ frequencies in the expected range for terminal carbonyl ligands $\left(2050-1900 \mathrm{~cm}^{-1}\right) .{ }^{1} \mathrm{H}-\mathrm{NMR}$ data of the new complexes $\mathbf{1 - 8}$ are given in Table 1 . These spectra show typical resonances in the range $\delta$ 4.9-4.6 ppm for the cyclopentadienyl ring protons and in the range $\delta 0.41-0.11$ for the $\mathrm{SiMe}_{2}$ protons. The upfield shifts of the methyl resonances in complexes 5-8 indicate the replacement of chlorine by oxygen bonded to silicon. The ${ }^{13} \mathrm{C}-\mathrm{NMR}$ data of these complexes (Table 2) also show the selective substitution of chlorine by oxygen in complexes $\mathbf{5 - 8}$, as methyl resonances of these complexes are shifted upfield with respect to the same resonances in complexes 1-4, whereas no significant differences are observed for the carbonyl groups of complexes $\mathbf{3}, \mathbf{6}$ and $\mathbf{8}$.

The ${ }^{1} \mathrm{H}-\mathrm{NMR}$ spectra of the hydrido complexes show high-field singlets between $\delta-7.3$ and $-5.5 \mathrm{ppm}$ with $\mathrm{W}$ satellites resolved for 2 . The ${ }^{13} \mathrm{C}$-NMR spectra of the hydrido complexes recorded at room temperature show, in all cases, a unique broad resonance for the carbonyl carbons, whereas the chloro carbonyl complexes show two resonances at room temperature. This different behaviour may be related to the low-energy barriers to hydride motion between piano stool legs [11].

Complexes 9, 10, 12 and 14 are paramagnetic and were characterized by their analytical composition and IR spectra and in the case of $\mathbf{1 2}$ by its reactivity to give the diamagnetic complex 13 . The ${ }^{1} \mathrm{H}-\mathrm{NMR}$ spectrum of complex 13 shows two signals for the protons of the cyclopentadienyl ring, one singlet at $\delta 1.02 \mathrm{ppm}$ for the ${ }^{t} \mathrm{Bu}$ group of the imido ligand and one singlet at $\delta 0.79$ ppm for the methyl protons of the $\mathrm{SiMe}_{2}$ group. The ${ }^{13} \mathrm{C}-\mathrm{NMR}$ spectrum of $\mathbf{1 3}$ is consistent with its formulation as an imido tungsten(VI) complex (see Section 4).

The spectroscopic data for complex 11 suggest a dimeric structure with terminal cyclopentadienyl moi- eties and four bridging chlorine atoms, similar to the structure found for related molybdenum complexes [12]. The small difference found in the ${ }^{1} \mathrm{H}-\mathrm{NMR}$ spectrum, between the two signals due to the protons of the cyclopentadienyl group and its diamagnetic character is consistent with the presence of a single metal-metal bond between the two molybdenum centres.

\section{Conclusions}

The synthesis of new chlorodimethylsilyl-substituted mono cyclopentadienyl tricarbonyl hydrido $\left[\mathrm{MCp}^{\mathrm{Cl}}-\right.$ $\left.(\mathrm{CO})_{3} \mathrm{H}\right]$ and chloro $\left[\mathrm{MCp}^{\mathrm{Cl}}(\mathrm{CO})_{3} \mathrm{Cl}\right]$ molybdenum(II) and tungsten(II) complexes was carried out following typical reported procedures. A comparative study of the reactivity of the two types of $\mathrm{Si}-\mathrm{Cl}$ and $\mathrm{Mo}-\mathrm{Cl}$ bonds present in the molybdenum complex shows that the $\mathrm{Si}-\mathrm{Cl}$ bond reacts selectively with water and anhydrous $\mathrm{LiOH}$ to afford hydroxosilyl complexes $\left[\mathrm{MoCp}{ }^{\mathrm{OH}}(\mathrm{CO})_{3} \mathrm{X}\right]$ due to the lower Lewis acidity of the molybdenum(II) centre. Oxidation of carbonyl complexes with $\mathrm{PCl}_{5}$ gave the cyclopentadienyl tetrachloro metal derivatives $\left[\mathrm{MCp}^{\mathrm{Cl}} \mathrm{Cl}_{4}\right]$, which were transformed into the corresponding imido molybdenum(V) and tungsten $(\mathrm{V})$ complexes $\left[\mathrm{MCp}^{\mathrm{Cl}} \mathrm{Cl}_{2}(\mathrm{NR})\right]$ by reaction with suitable amines in the presence of triethylamine. Subsequent oxidation with $\mathrm{PCl}_{5}$ was only possible with the imido tungsten complex to give the new diamagnetic cyclopentadienyl imido tungsten(VI) derivative $\left[\mathrm{WCp}^{\mathrm{Cl}}\left(\mathrm{N}^{t} \mathrm{Bu}\right) \mathrm{Cl}_{3}\right]$.

\section{Experimental}

All manipulations were performed under an inert atmosphere of argon using standard Schlenck techniques or a dry box. Solvents used were dried previously and freshly distilled under argon: tetrahydrofuran from sodium benzophenone ketyl; toluene from sodium; hexane from sodium-potassium; $\mathrm{CCl}_{4}$ over calcium hydride. Unless otherwise stated, reagents were 
obtained from commercial sources and used as received. Amines, $\mathrm{NH}_{2}^{t} \mathrm{Bu}$ and $\mathrm{NH}_{2}\left(2,6-\left(\mathrm{Me}_{2}\right)-\mathrm{C}_{6} \mathrm{H}_{3}\right)$ were purchased from commercial sources, dried over calcium hydride and then purified by distillation under argon before use. $\mathrm{C}_{5} \mathrm{H}_{5} \mathrm{SiMe}_{2} \mathrm{Cl}$ [13]. $\mathrm{Mo}(\mathrm{CO})_{3}(\mathrm{NCMe})_{3}$ [14] and $\mathrm{W}(\mathrm{CO})_{3}(\mathrm{NCMe})_{3}[14]$ were prepared according to reported methods.

IR spectra were recorded in Nujol mulls between CsI pellets over the range $4000-200 \mathrm{~cm}^{-1}$ on a PerkinElmer 583 spectrophotometer. ${ }^{1} \mathrm{H}$ - and ${ }^{13} \mathrm{C}-\mathrm{NMR}$ spectra were recorded on a Varian Unity VXR-300 or Varian Unity 500 Plus instruments. Chemical shifts $(\delta$ ppm) were measured relative to residual ${ }^{1} \mathrm{H}$ and ${ }^{13} \mathrm{C}$ resonances for benzene- $\mathrm{d}_{6}$ and chloroform- $\mathrm{d}_{1}$ used as solvents and coupling constants are in $\mathrm{Hz}$. C, H and N analyses were carried out with a Perkin-Elmer $240 \mathrm{C}$ microanalyzer.

\section{1. $\left[\mathrm{Mo}\left(\eta^{5}-\mathrm{C}_{5} \mathrm{H}_{4} \mathrm{SiMe}_{2} \mathrm{Cl}\right)(\mathrm{CO})_{3} \mathrm{H}\right] \mathrm{I}$}

Chloro(cyclopentadienyl)dimethylsilane $(4.22 \mathrm{ml}$, $26.7 \mathrm{mmol})$ was added to a THF $(75 \mathrm{ml})$ solution of $\left[\mathrm{Mo}(\mathrm{CO})_{3}\left(\mathrm{CH}_{3} \mathrm{CN}\right)_{3}\right](8.1 \mathrm{~g}, 26.7 \mathrm{mmol})$. The starting yellow solution was stirred for $2 \mathrm{~h}$ at reflux, turning to a brown colour. The solvent was removed completely in vacuo and the resulting brown oil extracted into $n$-hexane $(2 \times 10 \mathrm{ml})$ to give an orange-brown oil characterized as 1 (8.56 g, 94\%). IR (CsI, cm $\left.{ }^{-1}\right)$ : 2029 s, $1940 \mathrm{~s}$, $1259 \mathrm{~s}, 1040 \mathrm{~m}, 808 \mathrm{~s}, 489 \mathrm{~m} .{ }^{1} \mathrm{H}-\mathrm{NMR}\left(\mathrm{C}_{6} \mathrm{D}_{6}\right): \delta 4.75$, $4.69\left(\mathrm{AA}^{\prime}\right.$ and $\mathrm{BB}^{\prime}$ parts of an $\mathrm{AA}^{\prime} \mathrm{BB}^{\prime}$ spin system, $4 \mathrm{H}$, $\left.\mathrm{C}_{5} H_{4}\right), 0.32\left(\mathrm{~s}, 6 \mathrm{H},-\mathrm{Si} M e_{2} \mathrm{Cl}\right),-5.6\left(\mathrm{~s}, 1 \mathrm{H}, \mathrm{H}_{\text {hydride }}\right)$. ${ }^{13} \mathrm{C}\left\{{ }^{1} \mathrm{H}\right\}-\mathrm{NMR}\left(\mathrm{C}_{6} \mathrm{D}_{6}\right): \delta 226,7(\mathrm{~s}, \mathrm{CO}), 104.7$ (s, $\left.C_{i p s o}\right)$, $94.3\left(\mathrm{~s}, C_{5} \mathrm{H}_{4}\right), 94.1\left(\mathrm{~s}, C_{5} \mathrm{H}_{4}\right), 2.57\left(\mathrm{~s},-\mathrm{Si} M e_{2} \mathrm{Cl}\right)$. Anal. Calc. for $\mathrm{C}_{10} \mathrm{H}_{11} \mathrm{ClO}_{3} \mathrm{SiMo}$ : C, 35.35; H, 3.53. Found: C, 35.16; H, 3.42.

\section{2. $\left[\mathrm{W}\left(\eta^{5}-\mathrm{C}_{5} \mathrm{H}_{4} \mathrm{SiMe}_{2} \mathrm{Cl}\right)(\mathrm{CO})_{3} \mathrm{H}\right] 2$}

Chloro(cyclopentadienyl)dimethylsilane $(1.25 \mathrm{ml}, 8.0$ mmol) was added to a THF $(30 \mathrm{ml})$ solution of $\left[\mathrm{W}(\mathrm{CO})_{3}\left(\mathrm{CH}_{3} \mathrm{CN}\right)_{3}\right](3.08 \mathrm{~g}, 7.8 \mathrm{mmol})$. The starting yellow solution was refluxed for $3 \mathrm{~h}$ turning to a brown colour. The solvent was removed under vacuum and the resulting brown oil extracted with $n$-hexane $(2 \times 10$ $\mathrm{ml})$ to give a yellow-brown oil characterized as $\mathbf{2}$ $(90 \%)$. Complex 2 can be isolated in small amounts as a yellow crystalline solid upon treatment of the oil with cold hexane $(1 \mathrm{ml})$, although it reverts to an oil after several hours at room temperature and both oil and solid show the same chemical behavior. IR (CsI, $\left.\mathrm{cm}^{-1}\right)$ : $2022 \mathrm{~s}, 1931 \mathrm{~s}, 1258 \mathrm{~s}, 1041 \mathrm{~m}, 806 \mathrm{~s}, 492 \mathrm{~m}$, $429 \mathrm{~m} .{ }^{1} \mathrm{H}-\mathrm{NMR}\left(\mathrm{C}_{6} \mathrm{D}_{6}\right): \delta 4.66\left(\mathrm{~m}, 4 \mathrm{H}, \mathrm{C}_{5} H_{4}\right), 0.32(\mathrm{~s}$, $6 \mathrm{H},-\mathrm{SiMe} 2 \mathrm{Cl}),-7.33\left(\mathrm{~s}, 1 \mathrm{H}, \mathrm{J}_{\mathrm{wH}}=36.6 \mathrm{~Hz}, \mathrm{H}_{\text {hydride }}\right.$ ). ${ }^{13} \mathrm{C}\left\{{ }^{1} \mathrm{H}\right\}$-NMR $\left(\mathrm{C}_{6} \mathrm{D}_{6}\right): \delta 216.3\left(\mathrm{~s}, J_{\mathrm{WC}}=143.1 \mathrm{~Hz}\right.$, $C \mathrm{O}), 94.2\left(\mathrm{~s}, C_{i p s o}\right), 93.5\left(\mathrm{~s}, C_{5} \mathrm{H}_{4}\right), 92.9\left(\mathrm{~s}, C_{5} \mathrm{H}_{4}\right), 2.5$ (s, $-\mathrm{SiMe} \mathrm{Cl}_{2}$ ). Anal. Calc. for $\mathrm{C}_{10} \mathrm{H}_{11} \mathrm{ClO}_{3} \mathrm{SiW}$ : C, 28.14; H, 2.57. Found: C, 27.9; H, 2.00 .

\section{3. $\left[\mathrm{Mo}\left(\eta^{5}-\mathrm{C}_{5} \mathrm{H}_{4} \mathrm{SiMe}_{2} \mathrm{Cl}\right)(\mathrm{CO})_{3} \mathrm{Cl}\right] 3$}

$\mathrm{CCl}_{4}(3 \mathrm{ml}, 31.1 \mathrm{mmol})$ was added to a $\mathrm{CH}_{2} \mathrm{Cl}_{2}(30$ $\mathrm{ml})$ solution of $1(6.82 \mathrm{~g}, 20.13 \mathrm{mmol})$. The mixture was stirred for $24 \mathrm{~h}$ at room temperature to give an orange solution. The solvent was removed under vacuum and the resulting orange oil was extracted into $n$-hexane (10 $\mathrm{ml}$ ) and cooled to $-40^{\circ} \mathrm{C}$ to give an orange solid which was filtered and dried in vacuo to be characterized as $\mathbf{3}$ in $95 \%$ yield. IR (CsI, $\mathrm{cm}^{-1}$ ): $2056 \mathrm{~s}, 1985 \mathrm{~s}, 1260 \mathrm{~s}$, $1167 \mathrm{~s}, 1032 \mathrm{~m}, 809 \mathrm{~s}, 470 \mathrm{~m} .{ }^{1} \mathrm{H}-\mathrm{NMR}\left(\mathrm{C}_{6} \mathrm{D}_{6}\right): \delta 4.69$, $4.52\left(\mathrm{AA}^{\prime}\right.$ and $\mathrm{BB}^{\prime}$ parts of an $\mathrm{AA}^{\prime} \mathrm{BB}^{\prime}$ spin system, $4 \mathrm{H}$, $\left.\mathrm{C}_{5} H_{4}\right), 0.41\left(\mathrm{~s}, 6 \mathrm{H},-\mathrm{Si} M \mathrm{e}_{2} \mathrm{Cl}\right) .{ }^{13} \mathrm{C}\left\{{ }^{1} \mathrm{H}\right\}-\mathrm{NMR}\left(\mathrm{C}_{6} \mathrm{D}_{6}\right)$ : $\delta 241.4(\mathrm{~s}, 1 \mathrm{C}, \mathrm{CO}), 223.9(\mathrm{~s}, 2 \mathrm{C}, \mathrm{CO}), 98.9$ (s, $\left.C_{i p s o}\right)$, $104.8\left(\mathrm{~s}, C_{5} \mathrm{H}_{4}\right), 95.6\left(\mathrm{~s}, C_{5} \mathrm{H}_{4}\right), 2.36\left(\mathrm{~s},-\mathrm{Si}_{M e_{2} \mathrm{Cl}}\right)$. Anal. Calc. for $\mathrm{C}_{10} \mathrm{H}_{10} \mathrm{Cl}_{2} \mathrm{O}_{3} \mathrm{SiMo}$ : C, 32.19; H, 2.68 . Found: C, 31.89; H, 2.90.

\section{4. $\left[\mathrm{W}\left(\eta^{5}-\mathrm{C}_{5} \mathrm{H}_{4} \mathrm{SiMe}_{2} \mathrm{Cl}\right)(\mathrm{CO})_{3} \mathrm{Cl}\right] 4$}

$\mathrm{CCl}_{4}(3 \mathrm{ml})$ was added to a $\mathrm{CH}_{2} \mathrm{Cl}_{2}(30 \mathrm{ml})$ solution of $2(1.5 \mathrm{~g}, 3.25 \mathrm{mmol})$ and the mixture was stirred for $24 \mathrm{~h}$ at room temperature to give an orange solution. The solvent was removed under vacuum and the resulting orange oil was extracted into $n$-hexane $(10 \mathrm{ml})$ and cooled to $-40^{\circ} \mathrm{C}$. An orange crystalline solid

Table 2

${ }^{13} \mathrm{C}-\mathrm{NMR}\left(\mathrm{C}_{6} \mathrm{D}_{6}\right)^{\mathrm{a}}$ data for complexes $\mathrm{MCp}(\mathrm{CO})_{3} \mathrm{X}(\mathrm{X}=\mathrm{H}, \mathrm{Cl})$

\begin{tabular}{llll}
\hline Complex & $-\mathrm{C}_{5} \mathrm{H}_{4^{-}}$ & $-\mathrm{SiMe}_{2}-$ & $\mathrm{CO}$ \\
\hline $\mathrm{MoCp}^{\mathrm{Cl}}(\mathrm{CO})_{3} \mathrm{H}(\mathbf{1})$ & $104.7\left(\mathrm{C}_{i p s o}\right), 94.3,94.1$ & $2.57(\mathrm{~s})$ & $226.7(\mathrm{~s}, 3 \mathrm{C})$ \\
$\mathrm{WCp}^{\mathrm{Cl}}(\mathrm{CO})_{3} \mathrm{H}(\mathbf{2})$ & $94.2\left(\mathrm{C}_{i p s o}\right), 93.5,92.9$ & $2.50(\mathrm{~s})$ & $216.3\left(\mathrm{~s}, 3 \mathrm{C}, J_{W C}=143.1\right)$ \\
$\mathrm{MoCp}^{\mathrm{Cl}}(\mathrm{CO})_{3} \mathrm{Cl}(\mathbf{3})$ & $98.9\left(\mathrm{C}_{i p s o}\right), 104.8,95.6$ & $2.36(\mathrm{~s})$ & $241.4,223.9(\mathrm{~s}, 1 \mathrm{C}, \mathrm{s}, 2 \mathrm{C})$ \\
$\mathrm{WCp}^{\mathrm{Cl}}(\mathrm{CO})_{3} \mathrm{Cl}(\mathbf{4})$ & $96.2\left(\mathrm{C}_{i p s o}\right), 102.7,94.3$ & $2.20(\mathrm{~s})$ & $230.7,215.3(\mathrm{~s}, 1 \mathrm{C}, \mathrm{s}, 2 \mathrm{C})$ \\
{$\left[\mathrm{Mo}(\mathrm{CO})_{3} \mathrm{H}\right]_{2}\left(\mu-\mathrm{Cp}^{\mathrm{O}}\right)(\mathbf{5})$} & $99.3\left(\mathrm{C}_{i p s o}\right), 95.0,93.7$ & $1.22(\mathrm{~s})$ & $227.5(\mathrm{~s}, 3 \mathrm{C})$ \\
{$\left[\mathrm{Mo}(\mathrm{CO})_{3} \mathrm{Cl}\right]_{2}\left(\mu-\mathrm{Cp}^{\mathrm{O}}\right)(\mathbf{6})$} & $101.3\left(\mathrm{C}_{i p s o}\right), 104.6,95.8$ & $1.26(\mathrm{~s})$ & $242.5,224.7(\mathrm{~s}, 1 \mathrm{C}, \mathrm{s}, 2 \mathrm{C})$ \\
$\mathrm{MoCp}{ }^{\mathrm{OH}}(\mathrm{CO})_{3} \mathrm{Cl}(\mathbf{8})$ & $103.4\left(\mathrm{C}_{i p s o}\right), 105.3,93.9$ & $0.85(\mathrm{~s})$ & $242.2,224.8(\mathrm{~s}, 1 \mathrm{C}, \mathrm{s}, 2 \mathrm{C})$ \\
\hline
\end{tabular}

\footnotetext{
${ }^{\mathrm{a}}$ Chemical shifts are given in ppm. Coupling constants are given in $\mathrm{Hz}$.
} 
precipitated which after being filtered and dried in vacuo was characterized as 4 (90\% yield). ${ }^{1} \mathrm{H}-\mathrm{NMR}$ $\left(\mathrm{C}_{6} \mathrm{D}_{6}\right): \delta 4.66(\mathrm{~m}, 4 \mathrm{H}), 0.41 \quad\left(\mathrm{~s}, 6 \mathrm{H},-{ }_{-} \mathrm{Si} M e_{2} \mathrm{Cl}\right)$. ${ }^{13} \mathrm{C}\left\{{ }^{1} \mathrm{H}\right\}$-NMR $\left(\mathrm{C}_{6} \mathrm{D}_{6}\right): \delta 230.7(\mathrm{~s}, 1 \mathrm{C}, \mathrm{CO}), 215.3(\mathrm{~s}$, 2C, CO), 96.2 (s, $\left.C_{i p s o}\right), 102.7\left(\mathrm{~s}, C_{5} \mathrm{H}_{4}\right), 94.3\left(\mathrm{~s}, C_{5} \mathrm{H}_{4}\right)$, $2.2(\mathrm{~s},-\mathrm{SiMe} 2 \mathrm{Cl})$. Anal. Calc. for $\mathrm{C}_{10} \mathrm{H}_{10} \mathrm{Cl}_{2} \mathrm{O}_{3} \mathrm{SiW}: \mathrm{C}$, 26.04; H, 2.17. Found: C, 26.42; H, 2.22.

\section{5. $\left[\left\{\mathrm{Mo}(\mathrm{CO})_{3} \mathrm{H}_{2}\left(\eta^{5}-\mathrm{C}_{5} \mathrm{H}_{4}-\mathrm{SiMe}_{2}-\mathrm{O}-\mathrm{SiMe}{ }_{2}-\eta^{5}-\right.\right.\right.$ $\left.\left.\mathrm{C}_{5} \mathrm{H}_{4}\right)\right] 5$}

Deoxygenated water $(27 \mu \mathrm{l}, 1.49 \mathrm{mmol})$ was added by syringe to a toluene $(30 \mathrm{ml})$ solution of $\mathbf{1}(0.5 \mathrm{~g}, 1.49$ $\mathrm{mmol}$ ) and the mixture was stirred for $16 \mathrm{~h}$ at room temperature to give a red solution. The solvent was removed under vacuum and the residue was extracted into $\mathrm{n}$-hexane $(25 \mathrm{ml})$. The hexane solution was concentrated and stored at $-40^{\circ} \mathrm{C}$ overnight. A solid precipitated which after being filtered and dried in vacuo was characterized as $5(0.57 \mathrm{~g}, 50 \%)$. IR (CsI, $\left.\mathrm{cm}^{-1}\right)$ : 2024 s, $1951 \mathrm{~s}, 1258 \mathrm{~s}, 1043 \mathrm{~m}, 823 \mathrm{~s}, 489 \mathrm{~m} .{ }^{1} \mathrm{H}-\mathrm{NMR}$ $\left(\mathrm{C}_{6} \mathrm{D}_{6}\right): \delta 4.83,4.79\left(\mathrm{AA}^{\prime}\right.$ and $\mathrm{BB}^{\prime}$ parts of an $\mathrm{AA}^{\prime} \mathrm{BB}^{\prime}$ spin system, $\left.4 \mathrm{H}, \mathrm{C}_{5} H_{4}\right), 0.17\left(\mathrm{~s}, 6 \mathrm{H},-\mathrm{Si}_{2} \mathrm{O}_{2} \mathrm{O}-\right)$, $5.53\left(\mathrm{~s}, 1 \mathrm{H}, \mathrm{H}_{\text {hydride }}\right) \cdot{ }^{13} \mathrm{C}\left\{{ }^{1} \mathrm{H}\right\}-\mathrm{NMR}\left(\mathrm{C}_{6} \mathrm{D}_{6}\right): \delta 227.5$ (s, CO), $99.3\left(\mathrm{~s}, C_{i p s o}\right), 95.0\left(\mathrm{~s}, C_{5} \mathrm{H}_{4}\right), 93.7\left(\mathrm{~s}, C_{5} \mathrm{H}_{4}\right)$, $1.22\left(\mathrm{~s},-\mathrm{Si} M e_{2} \mathrm{O}_{-}\right)$. Anal. Calc. for $\mathrm{C}_{20} \mathrm{H}_{22} \mathrm{O}_{7} \mathrm{Si}_{2} \mathrm{Mo}_{2}$ : C, 38.57; H, 3.54. Found: C, 39.31; H, 3.69.

\section{6. $\left[\left\{\mathrm{Mo}(\mathrm{CO})_{3} \mathrm{Cl}_{2}\left(\eta^{5}-\mathrm{C}_{5} \mathrm{H}_{4}-\mathrm{SiMe}_{2}-\mathrm{O}-\mathrm{SiMe}_{2}-\eta^{5}-\right.\right.\right.$ $\left.\left.\mathrm{C}_{5} \mathrm{H}_{4}\right)\right] \mathrm{G}$}

This complex was obtained by the same procedure described for 5 but starting from complex $3(0.5 \mathrm{~g}, 1.34$ $\mathrm{mmol})$ and deoxygenated water $(24 \mu \mathrm{l}, 1.34 \mathrm{mmol})$, as an orange-red solid $(0.91 \mathrm{~g}, 98 \%)$. IR $\left(\mathrm{CsI}, \mathrm{cm}^{-1}\right)$ : $2045 \mathrm{~s}, 1977 \mathrm{~s}, 1261 \mathrm{~s}, 1052 \mathrm{~m}, 826 \mathrm{~s}, 475 \mathrm{~m} .{ }^{1} \mathrm{H}-\mathrm{NMR}$ $\left(\mathrm{C}_{6} \mathrm{D}_{6}\right): \delta 4.8,4.76\left(\mathrm{AA}^{\prime}\right.$ and $\mathrm{BB}^{\prime}$ parts of an $\mathrm{AA}^{\prime} \mathrm{BB}^{\prime}$ spin system, $\left.4 \mathrm{H}, \mathrm{C}_{5} H_{4}\right), 0.23\left(\mathrm{~s}, 6 \mathrm{H},-\mathrm{Si} \mathrm{Me}_{2} \mathrm{O}-\right.$ ). ${ }^{13} \mathrm{C}\left\{{ }^{1} \mathrm{H}\right\}$-NMR $\left(\mathrm{C}_{6} \mathrm{D}_{6}\right): \delta 242.5(\mathrm{~s}, 1 \mathrm{C}, \mathrm{CO}), 224.7$ (s, $2 \mathrm{C}, C \mathrm{O}), 101.3\left(\mathrm{~s}, C_{\text {ipso }}\right), 104.6\left(\mathrm{~s}, C_{5} \mathrm{H}_{4}\right), 95.8(\mathrm{~s}$, $\left.C_{5} \mathrm{H}_{4}\right), \quad 1.26$ (s, $-\mathrm{SiMe} \mathrm{O}_{-}$). Anal. Calc. for $\mathrm{C}_{20} \mathrm{H}_{20} \mathrm{Cl}_{2} \mathrm{O}_{7} \mathrm{Si}_{2} \mathrm{Mo}_{2}: \mathrm{C}, 34.75 ; \mathrm{H}, 2.89$. Found: C, 34.77; H, 3.15.

\section{7. $\left[\mathrm{Mo}\left(\eta^{5}-\mathrm{C}_{5} \mathrm{H}_{4} \mathrm{SiMe}_{2} \mathrm{OH}\right)(\mathrm{CO})_{3} \mathrm{H}\right] 7$}

LiOH $(0.0021 \mathrm{~g}, 0.009 \mathrm{mmol})$ was added to a benzene- $\mathrm{d}_{6}(0.5 \mathrm{ml})$ solution of $1(0.03 \mathrm{~g}, 0.09 \mathrm{mmol})$ in a NMR tube. The tube was introduced into an ultrasound bath for $3 \mathrm{~h}$ to improve the solubility of the LiOH. A ${ }^{1} \mathrm{H}-\mathrm{NMR}$ spectrum of the reaction mixture recorded after this time confirmed the formation of 7 . ${ }^{1} \mathrm{H}-\mathrm{NMR}\left(\mathrm{C}_{6} \mathrm{D}_{6}\right): \delta 4.83,4.76\left(\mathrm{AA}^{\prime}\right.$ and $\mathrm{BB}^{\prime}$ parts of an $\mathrm{AA}^{\prime} \mathrm{BB}^{\prime}$ spin system, 4H, $\left.\mathrm{C}_{5} H_{4}\right), 1.15(\mathrm{~s}, 1 \mathrm{H},-\mathrm{OH})$, $0.11\left(\mathrm{~s}, 6 \mathrm{H},-\mathrm{Si} M e_{2} \mathrm{OH}\right),-5.54\left(\mathrm{~s}, 1 \mathrm{H}, \mathrm{H}_{\text {hydride }}\right)$.

\section{8. $\left[\mathrm{Mo}\left(\eta^{5}-\mathrm{C}_{5} \mathrm{H}_{4} \mathrm{SiMe}_{2} \mathrm{OH}\right)(\mathrm{CO})_{3} \mathrm{Cl}\right] \boldsymbol{8}$}

LiOH $(0.027 \mathrm{~g}, 1.12 \mathrm{mmol})$ was added to a toluene $(25 \mathrm{ml})$ solution of $3(0.4 \mathrm{~g}, 1.12 \mathrm{mmol})$ and the reaction mixture was stirred in an ultrasound bath for 1 $\mathrm{h}$ and then $12 \mathrm{~h}$ at room temperature outside the bath. After filtration, all volatile compounds are removed under vacuum and the residue washed with $n$-hexane $(2 \times 10 \mathrm{ml})$ to give a red solid identified as $\mathbf{8}$. IR (CsI, $\mathrm{cm}^{-1}$ ): $3442 \mathrm{~m}, 2057 \mathrm{~s}, 1984 \mathrm{~s}, 1259 \mathrm{~s}, 1045 \mathrm{~m}, 822 \mathrm{~s}$, $476 \mathrm{~m} .{ }^{1} \mathrm{H}-\mathrm{NMR}\left(\mathrm{C}_{6} \mathrm{D}_{6}\right)$ : 4.81, $4.44\left(\mathrm{AA}^{\prime}\right.$ and $\mathrm{BB}^{\prime}$ parts of an $\mathrm{AA}^{\prime} \mathrm{BB}^{\prime}$ spin system, $\left.4 \mathrm{H}, \mathrm{C}_{5} H_{4}\right), 3.03(\mathrm{~s}, 1 \mathrm{H}$, $-\mathrm{OH}), \quad 0.22\left(\mathrm{~s}, \quad 6 \mathrm{H}, \quad-\mathrm{SiMe} e_{2} \mathrm{OH}\right),{ }^{13} \mathrm{C}\left\{{ }^{1} \mathrm{H}\right\}-\mathrm{NMR}$ $\left(\mathrm{C}_{6} \mathrm{D}_{6}\right): \delta 242.2(\mathrm{~s}, 1 \mathrm{C}, C \mathrm{O}), 224.8(\mathrm{~s}, 2 \mathrm{C}, \mathrm{CO}), 103.4$ (s, $\left.C_{\text {ipso }}\right), 105.3 \quad\left(\mathrm{~s}, C_{5} \mathrm{H}_{4}\right), 93.9 \quad\left(\mathrm{~s}, C_{5} \mathrm{H}_{4}\right), 0.85 \quad(\mathrm{~s}$, $-\mathrm{SiMe} 2 \mathrm{OH})$. Anal. Calc. for $\mathrm{C}_{10} \mathrm{H}_{11} \mathrm{ClO}_{4} \mathrm{SiMo}$ : C, 33.87; H, 3.10. Found: C, 34.48; H, 3.06.

\section{9. $\left[\mathrm{Mo}\left(\eta^{5}-\mathrm{C}_{5} \mathrm{H}_{4} \mathrm{SiMe}_{2} \mathrm{Cl}\right) \mathrm{Cl}_{4}\right] 9$}

A slight excess of $\mathrm{PCl}_{5}(8.41 \mathrm{~g}, 40.5 \mathrm{mmol})$ was slowly added to a solution of $3(6.85 \mathrm{~g}, 18.36 \mathrm{mmol})$ in toluene $(75 \mathrm{ml})$ and the mixture was stirred at $70^{\circ} \mathrm{C}$ for $12 \mathrm{~h}$ to give a dark red suspension. A pink precipitate was filtered, washed with $n$-hexane, dried under vacuum and identified as 9 (6.9 g, 95\%) by elemental analysis and IR spectroscopy. IR (CsI, $\mathrm{cm}^{-1}$ ): $1257 \mathrm{~s}$, $1051 \mathrm{~m}, 803 \mathrm{~m}, 495 \mathrm{~m}, 335$ s. Anal. Calc. for $\mathrm{C}_{7} \mathrm{H}_{10} \mathrm{Cl}_{5} \mathrm{SiMo}$ : C, 21.24; H, 2.78. Found: C, 22.04; H, 2.92.

This complex can also be obtained by oxidation of 1 with $\mathrm{PCl}_{5}$, but the yield is lower.

\subsection{0. $\left[\mathrm{W}\left(\eta^{5}-\mathrm{C}_{5} \mathrm{H}_{4} \mathrm{SiMe}_{2} \mathrm{Cl}\right) \mathrm{Cl}_{4}\right] \mathbf{1 0}$}

A slight excess of $\mathrm{PCl}_{5}(4.8 \mathrm{~g}, 23.0 \mathrm{mmol})$ was slowly added to a solution of $2(4.28 \mathrm{~g}, 10.0 \mathrm{mmol})$ in toluene $(50 \mathrm{ml})$ and the mixture was stirred at $70^{\circ} \mathrm{C}$ for $12 \mathrm{~h}$, while evolution of $\mathrm{CO}$ was observed. The resulting suspension was filtered and the orange-brown solid washed with $n$-hexane $(2 \times 10 \mathrm{ml})$ and dried in vacuo to yield complex $10(4.2 \mathrm{~g}, 85 \%)$. IR (CsI, $\left.\mathrm{cm}^{-1}\right)$ : $1256 \mathrm{~s}$, $1036 \mathrm{~m}, 802 \mathrm{~s}, 498 \mathrm{~m}, 322 \mathrm{~s}$. Anal. Calc. for $\mathrm{C}_{7} \mathrm{H}_{10} \mathrm{Cl}_{5} \mathrm{SiW}: \mathrm{C}, 17.41 ; \mathrm{H}, 2.07$. Found: $\mathrm{C}, 18.52 ; \mathrm{H}$, 2.33 .

\subsection{1. $\left[\mathrm{Mo}\left(\eta^{5}-\mathrm{C}_{5} \mathrm{H}_{4} \mathrm{SiMe}_{2} \mathrm{Cl}\right) \mathrm{Cl}_{2}\right]_{2} \mathrm{I1}$}

Fifty milliliters of a toluene solution of 9 (1.5 g, 3.79 mmol) were transferred via a canula over a $10 \%$ sodium amalgam $(0.18 \mathrm{~g}$ of $\mathrm{Na}, 7.58 \mathrm{mmol})$ and the reaction mixture was stirred for $16 \mathrm{~h}$. The solvent was removed under vacuum and the resulting residue was extracted into methylene chloride $(2 \times 30 \mathrm{ml})$. This solution was filtered, concentrated under vacuum and cooled to $-40^{\circ} \mathrm{C}$ to give a yellow-green solid characterized as $\mathbf{1 1}$ 
$(1.8 \mathrm{~g}, 73 \%)$. IR (CsI, $\left.\mathrm{cm}^{-1}\right): 1257 \mathrm{~s}, 1044 \mathrm{~m}, 803 \mathrm{~m}$, $491 \mathrm{w}, 328$ w. ${ }^{1} \mathrm{H}-\mathrm{NMR}\left(\mathrm{C}_{6} \mathrm{D}_{6}\right): \delta 5.91,5.67\left(\mathrm{AA}^{\prime}\right.$ and $\mathrm{BB}^{\prime}$ parts of an $\mathrm{AA}^{\prime} \mathrm{BB}^{\prime}$ spin system, $\left.4 \mathrm{H}, \mathrm{C}_{5} H_{4}\right), 0.06(\mathrm{~s}$, $\left.6 \mathrm{H},-\mathrm{Si}_{2} \mathrm{Cl}\right) .{ }^{13} \mathrm{C}\left\{{ }^{1} \mathrm{H}\right\}-\mathrm{NMR}\left(\mathrm{C}_{6} \mathrm{D}_{6}\right): \delta \quad 107.1$ (s, $\left.C_{\text {ipso }}\right), 111.7 \quad\left(\mathrm{~s}, \quad C_{5} \mathrm{H}_{4}\right), 108.8 \quad\left(\mathrm{~s}, \quad C_{5} \mathrm{H}_{4}\right), 1.3 \quad(\mathrm{~s}$, $-\mathrm{SiMe} 2 \mathrm{Cl}$ ). Anal. Calc. for $\mathrm{C}_{14} \mathrm{H}_{20} \mathrm{Cl}_{6} \mathrm{Si}_{2} \mathrm{Mo}_{2}: \mathrm{C}, 25.91$; H, 3.08. Found: C, 25.00; H, 3.39.

\subsection{2. $\left[\mathrm{W}\left(\eta^{5}-\mathrm{C}_{5} \mathrm{H}_{4} \mathrm{SiMe}_{2} \mathrm{Cl}\right)\left(\mathrm{N}^{t} \mathrm{Bu}\right) \mathrm{Cl}_{2}\right] \mathrm{12}$}

A stoichiometric amount of freshly distilled ${ }^{t} \mathrm{BuNH}_{2}$ $(0.63 \mathrm{ml}, 6.13 \mathrm{mmol})$ and two equivalents of $\mathrm{NEt}_{3}(1.70$ $\mathrm{ml}, 12.32 \mathrm{mmol})$ were added to a toluene $(50 \mathrm{ml})$ suspension of 10 ( $3 \mathrm{~g}, 6.13 \mathrm{mmol})$ and the mixture was stirred for $24 \mathrm{~h}$ to give a brown suspension. The ammonium salt formed was filtered off and all volatile compounds were removed in vacuum yielding a brown solid. Recrystallization of the residue from $n$-hexane $(30 \mathrm{ml})$ gave complex 12 in $70 \%$ yield. IR $\left(\mathrm{CsI}, \mathrm{cm}^{-1}\right)$ : $1322 \mathrm{~m}, 1258 \mathrm{~s}, 1026 \mathrm{~m}, 777 \mathrm{~s}, 494 \mathrm{~m}, 331 \mathrm{~m}$. Anal. Calc. for $\mathrm{C}_{11} \mathrm{H}_{19} \mathrm{Cl}_{3} \mathrm{NSiW}$ : C, 27.31; H, 3.93; N, 2.89 . Found: C, 26.72; H, 4.42; N, 2.72.

\subsection{3. $\left[W\left(\eta^{5}-C_{5} \mathrm{H}_{4} \mathrm{SiMe}_{2} \mathrm{Cl}\right)\left(\mathrm{N}^{t} \mathrm{Bu}\right) \mathrm{Cl}_{3}\right] \mathrm{13}$}

A toluene solution of $\mathbf{1 2}(2 \mathrm{~g}, 4.13 \mathrm{mmol})$ was treated with $\mathrm{PCl}_{5}(0.43 \mathrm{~g}, 2.06 \mathrm{mmol})$. The colour of the solution changed from brown to yellow and after stirring for $12 \mathrm{~h}$ at room temperature the insoluble solid was removed by filtration. The toluene solution was cooled to $-40^{\circ} \mathrm{C}$ to give complex 13 as a yellow microcrystalline solid (1.9 g, 90\% yield). IR (CsI, $\mathrm{cm}^{-1}$ ): $1317 \mathrm{~m}, 1256 \mathrm{~s}, 1055 \mathrm{~m}, 807 \mathrm{~s}, 492 \mathrm{~m}, 329 \mathrm{~m}$. ${ }^{1} \mathrm{H}-\mathrm{NMR}\left(\mathrm{C}_{6} \mathrm{D}_{6}\right): \delta 6.46,5.48\left(\mathrm{AA}^{\prime}\right.$ and $\mathrm{BB}^{\prime}$ parts of an $\mathrm{AA}^{\prime} \mathrm{BB}^{\prime}$ spin system, $\left.4 \mathrm{H}, \mathrm{C}_{5} H_{4}\right), 1.02\left(\mathrm{~s}, 9 \mathrm{H},{ }^{t} \mathrm{Bu}\right), 0.79$ (s, 6H, $-\mathrm{SiMe} 2 \mathrm{Cl}) .{ }^{13} \mathrm{C}\left\{{ }^{1} \mathrm{H}\right\}-\mathrm{NMR}\left(\mathrm{C}_{6} \mathrm{D} 6\right): \delta 122.6$ (s, $\left.C_{\text {ipso }}\right), 135.0 \quad\left(\mathrm{~s}, \quad C_{5} \mathrm{H}_{4}\right), 102.9 \quad\left(\mathrm{~s}, C_{5} \mathrm{H}_{4}\right), 77.0 \quad(\mathrm{~s}$, $\left.C\left(\mathrm{CH}_{3}\right)_{3}\right), 28.3\left(\mathrm{~s}, \mathrm{C}\left(\mathrm{CH}_{3}\right)_{3}\right), 1.1\left(\mathrm{~s},-\mathrm{Si} M e_{2} \mathrm{Cl}\right)$. Anal. Calc. for $\mathrm{C}_{11} \mathrm{H}_{19} \mathrm{Cl}_{4} \mathrm{NSiW}$ : C, 25.43; H, 3.66; N, 2.69 . Found: C, 25.63; H, 4.06; N, 2.59.

$$
\begin{aligned}
& \text { 4.14. }\left[\mathrm{Mo}\left(\eta^{5}-\mathrm{C}_{5} \mathrm{H}_{4} \mathrm{SiMe}{ }_{2} \mathrm{Cl}\right)\left(\mathrm{N}-2,6-\left(\mathrm{Me}_{2}\right)-\mathrm{C}_{6} \mathrm{H}_{3}\right) \mathrm{Cl}_{2}\right] \\
& \mathrm{14}
\end{aligned}
$$

A stoichiometric amount of freshly distilled 2,6- $\mathrm{Me}_{2}-$ $\mathrm{C}_{6} \mathrm{H}_{3} \mathrm{NH}_{2}(0.43 \mathrm{ml}, 3.5 \mathrm{mmol})$ and two equivalents of $\mathrm{NEt}_{3}(0.97 \mathrm{ml}, 7.0 \mathrm{mmol})$ were added to a toluene $(50$ $\mathrm{ml})$ suspension of $9(1.6 \mathrm{~g}, 3.5 \mathrm{mmol})$ and the mixture was stirred for $24 \mathrm{~h}$ to give a brown suspension. The ammonium salt formed was filtered off and all volatile compounds were removed in vacuo yielding an orange oil. Recrystallization of the residue from $n$-hexane $(30$ $\mathrm{ml})$ yielded $1.01 \mathrm{~g}(65 \%)$ of orange crystals of complex 14. IR (CsI, cm ${ }^{-1}$ ): $1580 \mathrm{w}, 1376 \mathrm{~m}, 1257 \mathrm{~s}, 1041 \mathrm{~m}$, $802 \mathrm{~s}, 494 \mathrm{~m}, 320 \mathrm{~m}$. Anal. Calc. for $\mathrm{C}_{15} \mathrm{H}_{19} \mathrm{Cl}_{3} \mathrm{NSiMo}$ : C, 40.59; H, 4.30; N, 3.16. Found: C, 39.77; H, 4.37; N, 2.76 .

\section{Acknowledgements}

The authors acknowledge DGICYT (project PB920178-C) for financial support.

\section{References}

[1] (a) G. Wilkinson, J. Am. Chem. Soc. 76 (1954) 209. (b) E.O. Fischer and W. Hafner, Z. Naturforsch. 10b (1955) 140. (c) E.O. Fischer, W. Hafner, H.O. Stahl, Z. Anorg. Allg. Chem. 282 (1955) 47.

[2] R. Poli, Chem Rev. 91 (1991) 509.

[3] (a) P. Gómez-Sal, E. de Jesús, A.I. Pérez, P. Royo, Organometallics 12 (1993) 4633. (b) F. Amor, P. Gómez-Sal, E. de Jesús, P. Royo, A.V. de Miguel, Organometallics 13 (1994) 4322. (c) F. Amor, E. de Jesús, P. Royo, A.V. de Miguel, Inorg. Chem. 34 (1995) in press. (d) F. Amor, E. de Jesús, A.I. Pérez, P. Royo, A.V. de Miguel, Organometallics 15 (1996) 365. (e) A.D. Hunter, P. Legzdins, J.T. Martín, L. Sánchez, Organomet. Synth. 3 (1986) 58. (f) N.H. Dryden, P. Legzdins, F.W.B. Einstein, R.H. Jones, Can. J. Chem. 66 (1988) 2100. (g) P. Legzdins, J.E. Veltheer, Acc. Chem. Res. 26 (1993) 41.

[4] (a) M.L.H. Green, P.C. Konidaris, P. Mountford, S.J. Simpson, J. Chem. Soc. Chem. Commun. (1992) 256. (b) U. Radius, J. Sundermeyer, Chem. Ber. 125 (1992) 2183. (c) J. Sundermeyer, U. Radius, C. Burschka, Chem. Ber. 125 (1992) 2379. (d) K. Köhler, H.W. Roesky, A. Herzog, H. Gornitzka, A. Steiner, I. Usón, Inorg. Chem. 35 (1996) 1773.

[5] (a) F.J. de la Mata, J. Gómez, P. Royo, J. Organomet. Chem. 564 (1998) 277. (b) P. Gómez-Sal, I. Jiménez, A. Martín, T. Pedraz, P. Royo, A. Sellés, A.V. de Miguel, Inorg. Chim. Acta (in press).

[6] See for example: (a) Murrell, in: J.J. Burton, R.L. Garten (Eds.), Advanced Materials in Catalysis, Academic Press, New York, 1977. (b) R.L. Pruett, Adv. Organomet. Chem. 17 (1979) 1. (c) C.U. Pittman, in: P. Hodge, D.C. Sherrington (Eds.), PolymerSupported Reactions in Organic Synthesis, Wiley, New York, 1980. (d) A. Akelah, D.C. Sherrington, Chem. Rev. 81 (1981) 557. (e) B. Klein, R.J. Kaziuskas, M.S. Wrighton, Organometallics 1 (1982) 1338. (f) B.L. Booth, G.C. Ofunne, C. Stacey, P.J.T. Tait, J. Organomet. Chem. 315, (1986) 143.

[7] See for example: (a) H. Brunner, R. Grassi, J. Watcher, B. Nuber, M.L. Ziegler, J. Organomet. Chem, 431 (1992) 143. (b) T.E. Bitterwolf, A.L. Rheingold, Organometallics, 10 (1991) 3856. (c) W. Abriel, J. Heck, J. Organomet. Chem. 302 (1986) 363. (d) J. Heck, K.A. Kriebisch, H. Mellinghoff, Chem. Ber. 121 (1988) 1753.

[8] The same complex can be prepared, in similar yield, by reaction of $\left[1,3,5-\mathrm{C}_{6} \mathrm{H}_{3} \mathrm{Me}_{3}\right] \mathrm{Mo}(\mathrm{CO})_{3}$ and $\mathrm{C}_{5} \mathrm{H}_{5} \mathrm{SiMe}_{2} \mathrm{Cl}$ in THF.

[9] (a) Ref. [4]. (b) M.D. Curtis, J.J. D'Errico, D.N. Duffy, P.S. Epstein, L.G. Bell, Organometallics 2 (1983) 1808.

[10] (a) S. Ciruelos, T. Cuenca, P. Gómez-Sal, A. Manzanero, P. Royo, Organometallics 14 (1995) 177. (b) M.I. Alcalde, P. Gómez-Sal, A. Martín, P. Royo, Organometallics (1998) in press.

[11] R. Pince, R. Poilblanc, A.S. Roussel, J. Organomet. Chem. 24 (1970) 445.

[12] (a) P.D. Grebenik, M.L.H. Green, A. Izquierdo, V.S.B. Mtetwa, K. Prout, J. Chem. Soc. Dalton Trans. (1987) 9. (b) M.L.H. Green, J.D. Hubert, P. Mountford, J. Chem Soc. Dalton Trans. (1990) 3793. (c) M.L.H. Green, P. Mountford, Chem. Soc. Rev. 21 (1992) 29.

[13] J. Hiermeier, F.H. Köhler, G. Muller, Organometallics 10 (1991) 1787.

[14] F. Edelmann, P. Behrens, S. Behrens, U. Behrens, J. Organomet. Chem. 310 (1986) 333. 